\title{
Seasonal cycling of phosphorus in the Southern Bight of the North Sea
}

\author{
C. van der Zee and L. Chou
}

Laboratoire d'Océanographie Chimique et Géochimie des Eaux, Université Libre de Bruxelles, Campus de la Plaine - CP 208, Boulevard du Triomphe, B-1050 Brussels, Belgium

Received: 22 September 2004 - Published in Biogeosciences Discussions: 12 October 2004

Revised: 10 January 2005 - Accepted: 14 January 2005 - Published: 18 February 2005

\begin{abstract}
We have investigated the seasonal cycle of nutrients, chlorophyll $a$, dissolved organic nitrogen (DON), and dissolved and particulate organic carbon (DOC and POC) for 10 stations in the Belgian coastal zone. Special attention was given to phosphorus speciation, i.e. dissolved inorganic and organic phosphorus (DIP and DOP) and particulate inorganic and organic phosphorus (PIP and POP).

Spatial and temporal trends of the inorganic nutrients and the organic species are discussed. The Belgian part of the southern North Sea is strongly influenced by the river plumes of the Rhine, Meuse and Scheldt resulting in northeast-southwest salinity gradient. Extrapolation of winter nutrient and DOC concentrations versus salinity plots yielded zero-salinity values typical of the river Scheldt. The polyphosphate concentration did not show any temporal trend, whereas both the phosphate and the DOP concentrations exhibited distinct seasonal variations. Silica or phosphorus was the potential limiting nutrient for phytoplankton growth based on elemental ratios.
\end{abstract}

\section{Introduction}

The Southern Bight of the North Sea receives nutrients from domestic, industrial and agricultural wastewater discharge, river inputs and atmospheric deposition. Most of these nutrients are linked to anthropogenic activities that have significantly increased the riverine flux of nitrogen $(\mathrm{N})$ and phosphorus (P) to the coastal zones of the North Sea (North Sea Task Force, 1993). The principal land source of another major nutrient, dissolved silicate ( $\mathrm{Si}$ ), has remained constant as it is not influenced by human activity but through chemical weathering of silicate minerals. The flux of dissolved Si from the rivers that reaches the coastal areas, however, has de-

Correspondence to: C. van der Zee

(cvdzee@ulb.ac.be) creased in some areas, for instance, from the Rhine (Conley et al., 1993 and references herein). As a consequence, the nutrient ratios in the riverine flux to the coastal zone have drastically changed. This results in a concomitant modification of phytoplankton species composition and thus of the functioning of the coastal ecosystem. For example, a reduced importance of the diatom bloom and the frequent occurrence of massive Phaeocystis blooms have been observed (Lancelot et al., 1987).

Turner et al. (2003a, b) reviewed data for dissolved inorganic nitrogen (DIN), dissolved inorganic phosphate (DIP) and dissolved silicate in the world's largest rivers in order to predict future aquatic nutrient limitations, assuming the predicted increase in fertilizer use (which has a N:P ratio of 26). The authors found that the coastal areas in northern Europe are most likely to have both P and Si limitation. Smith et al. (2003) compiled an extended database of nutrient loads from about 165 sites and found that even though the DIN and DIP follow different biogeochemical cycles, fluxes of DIN and DIP are tightly coupled with a constant ratio of about 18:1. At the Second International Conference on the Protection of the North Sea (in London, 1987), all countries surrounding the North Sea agreed on reducing the anthropogenic input of nutrients by 50\% between 1985 and 1995 for areas where nutrients cause pollution (Parcom, 1988). The 50\% reduction commitments by the North Sea bordering states were mostly achieved for phosphorus, but reductions for nitrogen were estimated to be on the order of $25 \%$ between 1985 and 1995 (Osparcom, 2000). Recently, Skogen et al. (2004) ran model scenarios for the years of 1988 and 1989 with reduced nutrient inputs from the rivers to the North Sea. Simulation results indicated that a 50\% decrease in the $\mathrm{N}$ and $\mathrm{P}$ loadings would lead to a decline in the primary production by $10-30 \%$ in the southern North Sea. The model simulation using a reduction only in the $\mathrm{P}$ load suggested that $\mathrm{P}$ would limit the primary production in the southern North Sea, while N would be limiting in the northern North Sea.

(C) 2005 Author(s). This work is licensed under a Creative Commons License. 


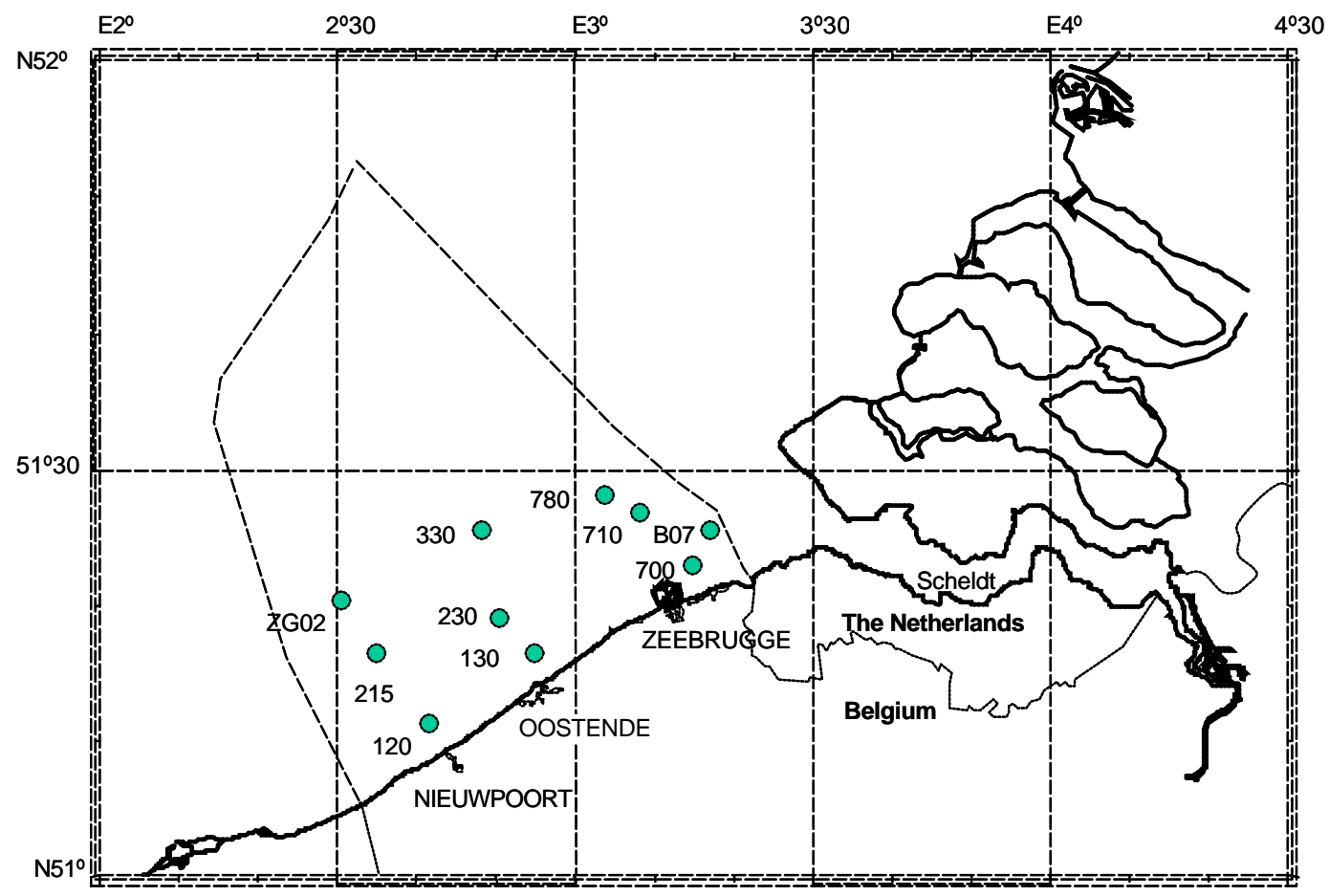

Fig. 1. Map of the Belgian coastal zone indicating the location of the ten stations.

Philippart et al. (2000) showed that the phytoplankton community changed drastically in the eutrophic Marsdiep (westernmost inlet of the Wadden Sea) both between 1976 and 1978 and again between 1987 and 1988, whereas it was stable before (1974-1976), in-between (1978-1987) and thereafter (1988-1994). These major changes coincide with changes in absolute and relative (total $\mathrm{N}$ : total P) nutrient concentrations. In 1977, the system shifted from a phosphorus-controlled situation, towards a nitrogencontrolled environment, and re-shifted towards $\mathrm{P}$ control in 1987-1988. This coincidence implies a strong relationship between N:P ratios and the phytoplankton community structure. Phosphate concentrations dropped a little further since 1992 in the Marsdiep and since 1994 (until 2000) a decrease in primary productivity, chlorophyll $a$ concentration and Phaeocystis cell numbers was observed (Cadée and Hegeman, 2002). These are the first signs of de-eutrophication.

The Belgian coastal zone is greatly influenced by the rivers Rhine, Meuse and the Scheldt (Van Bennekom and Wetsteijn, 1990; Lacroix et al., 2004). As observed generally in the North Sea, the phosphorus flux decreased more in recent years than the nitrogen flux from the Scheldt to the Belgian coastal zone. The annual phosphate $\left(\mathrm{PO}_{4}\right)$ load supplied by the river Scheldt to the Belgian coast was on average $0.032 \times 10^{9} \mathrm{~mol}$ between 1990 and 1993 , whereas about $0.066 \times 10^{9} \mathrm{~mol}$ were supplied annually in the 1980 s (Lenhart et al., 1996). The annual nitrate load, however, was on average $1.4 \times 10^{9} \mathrm{~mol}$ in the $1980 \mathrm{~s}$ and still $1.2 \times 10^{9}$ mol between
1990 and 1993 (Lenhart et al., 1996). Two major phytoplankton communities, the diatoms and Phaeocystis, dominate the nutrient removal in the Belgian coastal zone during the spring bloom. Tungaraza et al. (2003) measured the nutrient concentrations at station $330\left(51^{\circ} 26^{\prime} \mathrm{N}, 2^{\circ} 48.5^{\prime} \mathrm{E}\right)$ in the Belgian coastal zone between late winter and early summer in 1996 and 1997. They found that the $\mathrm{PO}_{4}$ concentration did not show a pronounced seasonal pattern. Silicate and nitrate, on the other hand, showed clear seasonal variations with the lowest concentrations observed at the end of spring and during summer. Rousseau et al. (2002) did observe a seasonal pattern in the phosphate concentrations at station 330 in 1995 . The $\mathrm{PO}_{4}$ concentration started to decrease between February and March with the onset of the early-spring diatom bloom. In the second half of May, the decline in the Phaeocystis and Rhizosolania spp. bloom corresponded to the lowest DIN $(3.3 \mu \mathrm{M}), \mathrm{Si}(\mathrm{OH})_{4}(0.9 \mu \mathrm{M})$ and $\mathrm{PO}_{4}(0.03 \mu \mathrm{M})$ concentrations recorded during spring. The lowest seasonal $\mathrm{pCO}_{2}$ values coincide with the Phaeocystis bloom and the lowest nutrient levels (Gypens et al., 2004).

These studies, however, focussed mainly on the role of nitrogen, silicon and carbon in the Belgian coastal zone, and the only phosphorus species measured was $\mathrm{PO}_{4}$. Little research has been devoted to the phosphorus cycle in the Belgian coastal zone, while this element is an important and potentially limiting nutrient. Also, with the changing N:P ratio of the riverine fluxes, recent data are required to assess the 
present nutrient situation of the ecosystem. In this context, we visited 10 stations located on the Belgian Continental Shelf over one year (from August 2002 to December 2003), giving particular attention to the speciation of phosphorus.

\section{Materials and methods}

\subsection{Study site and sampling methods}

The study area comprised the Belgian coastal zone of the southern North Sea (Fig. 1). This part of the North Sea is highly influenced by the eutrophied rivers Scheldt and Rhine/Meuse, and by oceanic water flowing from the Atlantic through the Channel into the North Sea. The gross primary production in the Belgian coastal zone was estimated to be $225 \mathrm{~g} \mathrm{C} \mathrm{m}^{-2} \mathrm{y}^{-1}$ (Gypens et al., 2004). The water column is completely mixed vertically throughout the year, due to the strong tidal currents and shallow water depth. The water depth ranges from $\sim 10-15 \mathrm{~m}$ for stations B07, 700, 710, 120,130 and 230 , to $\sim 18-28 \mathrm{~m}$ for the remaining stations 780, 330, 215 and ZG02. The 10 stations can be grouped along three near shore-offshore transects: one located close to the mouth of the Scheldt (stations 700, B07, 710 and 780), a second one near the city of Oostende (stations 130, 230 and 330) and the third most southern transect near Nieuwpoort (stations 120, 215 and ZG02). Surface waters were collected with Niskin bottles from $1 \mathrm{~m}$ water depth during near-monthly surveys with the RV Zeeleeuw in the Belgian coastal zone (Table 1 and Fig. 1). Samples were filtered for dissolved phosphorus speciation, nitrogen speciation, dissolved organic carbon (DOC) and dissolved silicate determination. The particulate phase was collected on filters for the measurement of chlorophyll $a$, suspended particulate matter (SPM), and carbon and phosphorus species.

\subsection{Chlorophyll $a$ and particulate organic carbon}

Chlorophyll $a$ was determined on GF/F filters after filtration of 250-ml seawater under low suction, following the fluorometric method of Yentsch and Menzel (1963). Filters were stored at $-20^{\circ} \mathrm{C}$ until analyses. For analysis, the filters were extracted with $90 \%$ acetone at $-20^{\circ} \mathrm{C}$ for $24 \mathrm{~h}$. Samples were centrifuged (10 min, $5500 \mathrm{rpm})$ and the fluorescence of the extract was measured with a Shimadzu RF-150 fluorometer, using an excitation wavelength of $430 \mathrm{~nm}$ and an emission wavelength of $663 \mathrm{~nm}$. The fluorescence was calibrated with a stock solution of pure chlorophyll $a$ (Merck).

Particulate organic carbon (POC) measurements were performed on particulate matter collected by filtration of seawater on precombusted $\left(4 \mathrm{~h}, 500^{\circ} \mathrm{C}\right) \mathrm{GF} / \mathrm{F}$ filters. POC was measured using a Fisions NA-1500 elemental analyser after carbonate removal from the filters by strong acid fumes overnight. Certified reference stream sediment (STSD-2) from the Geological Survey of Canada was used for the calibration.
Table 1. Sampling locations and dates.

\begin{tabular}{|c|c|c|c|}
\hline Station name & Latitude & Longitude & Sampling dates \\
\hline \multicolumn{3}{|c|}{ Nieuwpoort Transect } & 23 August 2002 \\
\hline 120 & $51^{\circ} 11.1^{\prime}$ & $2^{\circ} 42.0^{\prime}$ & 27 September 2002 \\
\hline 215 & $51^{\circ} 16.5^{\prime}$ & $2^{\circ} 36.8^{\prime}$ & 29 October 2002 \\
\hline \multirow[t]{2}{*}{ ZG02 } & $51^{\circ} 20.0^{\prime}$ & $2^{\circ} 30.0^{\prime}$ & 21 November 2002 \\
\hline & & & 23 December 2002 \\
\hline \multicolumn{3}{|c|}{ Oostende Transect } & 20 January 2003 \\
\hline 130 & $51^{\circ} 16.2^{\prime}$ & $2^{\circ} 54.2^{\prime}$ & 26 February 2003 \\
\hline 230 & $51^{\circ} 18.4^{\prime}$ & $2^{\circ} 51.0^{\prime}$ & 31 March 2003 \\
\hline \multirow[t]{3}{*}{330} & $51^{\circ} 26.0^{\prime}$ & $2^{\circ} 48.5^{\prime}$ & 25 April 2003 \\
\hline & & & 26 May 2003 \\
\hline & \multicolumn{2}{|c|}{ Scheldt Transect } & 30 June 2003 \\
\hline 700 & $51^{\circ} 22.6^{\prime}$ & $3^{\circ} 13.2^{\prime}$ & 31 July 2003 \\
\hline 710 & $51^{\circ} 26.5^{\prime}$ & $3^{\circ} 08.3^{\prime}$ & 28 August 2003 \\
\hline 780 & $51^{\circ} 28.3^{\prime}$ & $3^{\circ} 03.5^{\prime}$ & 26 September 2003 \\
\hline B07 & $51^{\circ} 25.9^{\prime}$ & $3^{\circ} 17.9^{\prime}$ & 9 December 2003 \\
\hline
\end{tabular}

\subsection{Dissolved Si and N species and DOC}

Water samples for silicate were taken in plastic bottles and filtered on a plastic filtration set. Dissolved silicate was measured following the method of Grasshoff et al. (1983). Nitrate, nitrite and ammonium were determined colorimetrically. Nitrate and nitrite were analysed with a Technicon Autoanalyzer system following Grasshoff et al. (1983). Ammonium was measured with the indophenol blue technique according to Koroleff (1969). The dissolved organic nitrogen (DON) was determined as the difference between total dissolved nitrogen and the dissolved inorganic nitrogen (nitrate, nitrite and ammonium). Total dissolved nitrogen (TDN) was measured by wet oxidation in alkaline persulphate $\left(120^{\circ} \mathrm{C}, 30 \mathrm{~min}\right)$ (Grasshoff et al., 1983). The precision of the TDN analysis was $1.0 \mu \mathrm{M}$. The DOC was determined with a Shimadzu TOC-5000 analyser using the widely accepted high-temperature catalytic oxidation (HTCO) technique (Sugimura and Suzuki, 1988; Suzuki, 1993).

\subsection{Phosphorus speciation}

Dissolved phosphorus species were determined after filtration through precombusted $\left(4 \mathrm{~h}, 500^{\circ} \mathrm{C}\right) \mathrm{GF} / \mathrm{F}$ filters, which were used for the particulate phosphorus speciation. Soluble reactive phosphorus, hereafter phosphate, was measured according to the method of Grasshoff et al. (1983). Dissolved inorganic phosphorus (DIP) was determined as phosphate after digestion with $9 \mathrm{~N} \mathrm{H}_{2} \mathrm{SO}_{4}\left(120^{\circ} \mathrm{C}, 30 \mathrm{~min}\right)$. DIP comprises phosphate and polyphosphates, although hydrolysis of acid-labile organic phosphorus compounds may also contribute to this parameter. Polyphosphate was determined as the difference between DIP and phosphate (Polyphosphate=DIP-PO 4 ). Total dissolved phosphorus (TDP) was measured by wet oxidation in acid persulphate 

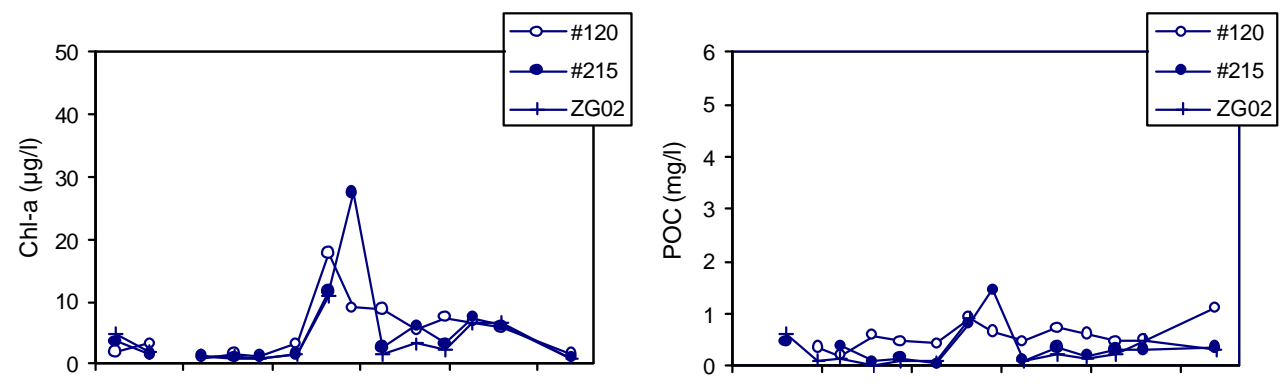

Aug-02 Nov-02 Feb-03 May-03 Aug-03 Nov-03

Aug-02 Nov-02 Feb-03 May-03 Aug-03 Nov-03
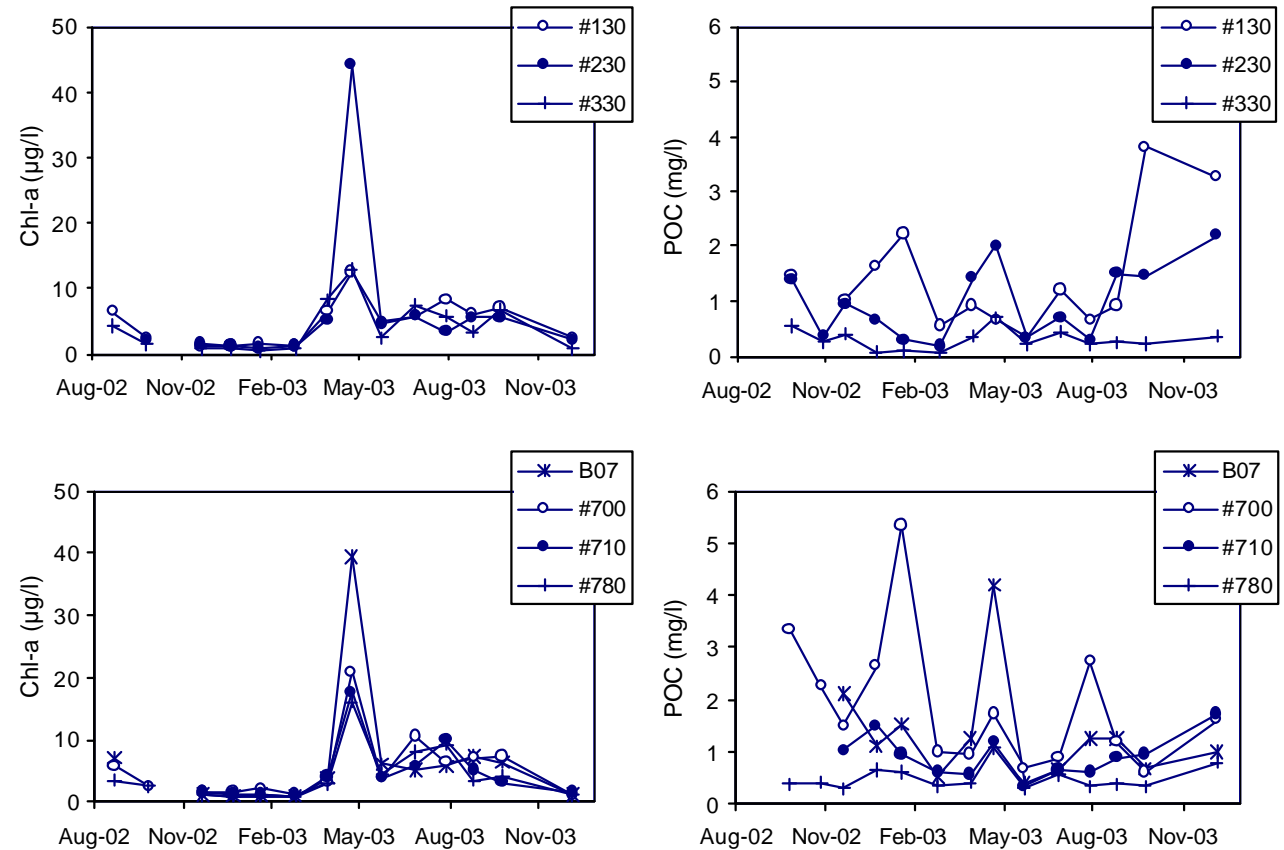

Fig. 2. Seasonal trend in the chlorophyll $a$ and the POC concentrations for the ten stations investigated. The stations are grouped per transect: on the Nieuwpoort transect stations 120, 215 and ZG02, on the Oostende transect stations 130, 230 and 330 and on the Scheldt transect stations B07, 700, 710 and 780 .

$\left(120^{\circ} \mathrm{C}, 30 \mathrm{~min}\right)$ (Grasshoff et al., 1983). The precision of the TDP analysis was $0.02 \mu \mathrm{M}$. Dissolved organic phosphorus (DOP) was subsequently calculated as the difference between TDP and phosphate as upper estimate (DOP=TDP$\mathrm{PO}_{4}$ ) and the difference between TDP and DIP as lower estimate. Filters for the total particulate phosphorus (TPP) determination were combusted at $500^{\circ} \mathrm{C}$ for $1.5 \mathrm{~h}$ with $\mathrm{MgSO}_{4}$ and subsequently extracted in $1 \mathrm{~N} \mathrm{HCl}$ for $24 \mathrm{~h}$ (Solorzano and Sharp, 1980). Filters for particulate inorganic phosphorus (PIP) were extracted in $1 \mathrm{~N} \mathrm{HCl}$ for $24 \mathrm{~h}$. Particulate organic phosphorus (POP) was calculated as the difference between TPP and PIP (POP=TPP-PIP). Additionally, the unfiltered water sample was digested by wet oxidation in acid persulphate, which gives the total phosphorus.

In order to distinguish the contribution to POP of resuspended sediment from that of phytoplankton, we have corrected the POP concentration as follows. The POP concen- tration resulting from resuspended sediment was estimated by multiplying the PIP concentration at a given station during a given campaign with the lowest POP/PIP ratio of the SPM at each station. This value was then subtracted from the POP concentration at the given station during the given campaign. The lowest POP/PIP ratio was used because resuspended sediment is expected to have a lower POP/PIP ratio than pelagic material. Thus, corrected $\mathrm{POP}=\mathrm{POP}-$ $\left(\mathrm{PIP} \times(\mathrm{POP} / \mathrm{PIP})_{\text {lowest }}\right)$. The lowest POP/PIP ratios range from 0.22 to 0.83 for the individual stations. The average POP/PIP ratio is 0.61 , which compares well with the value of 0.53 for the $\mathrm{POP} /(\mathrm{Fe}$-bound $\mathrm{P})$ ratio in the Wadden Sea near the Elbe estuary (van Beusekom and Brockmann, 1998). 

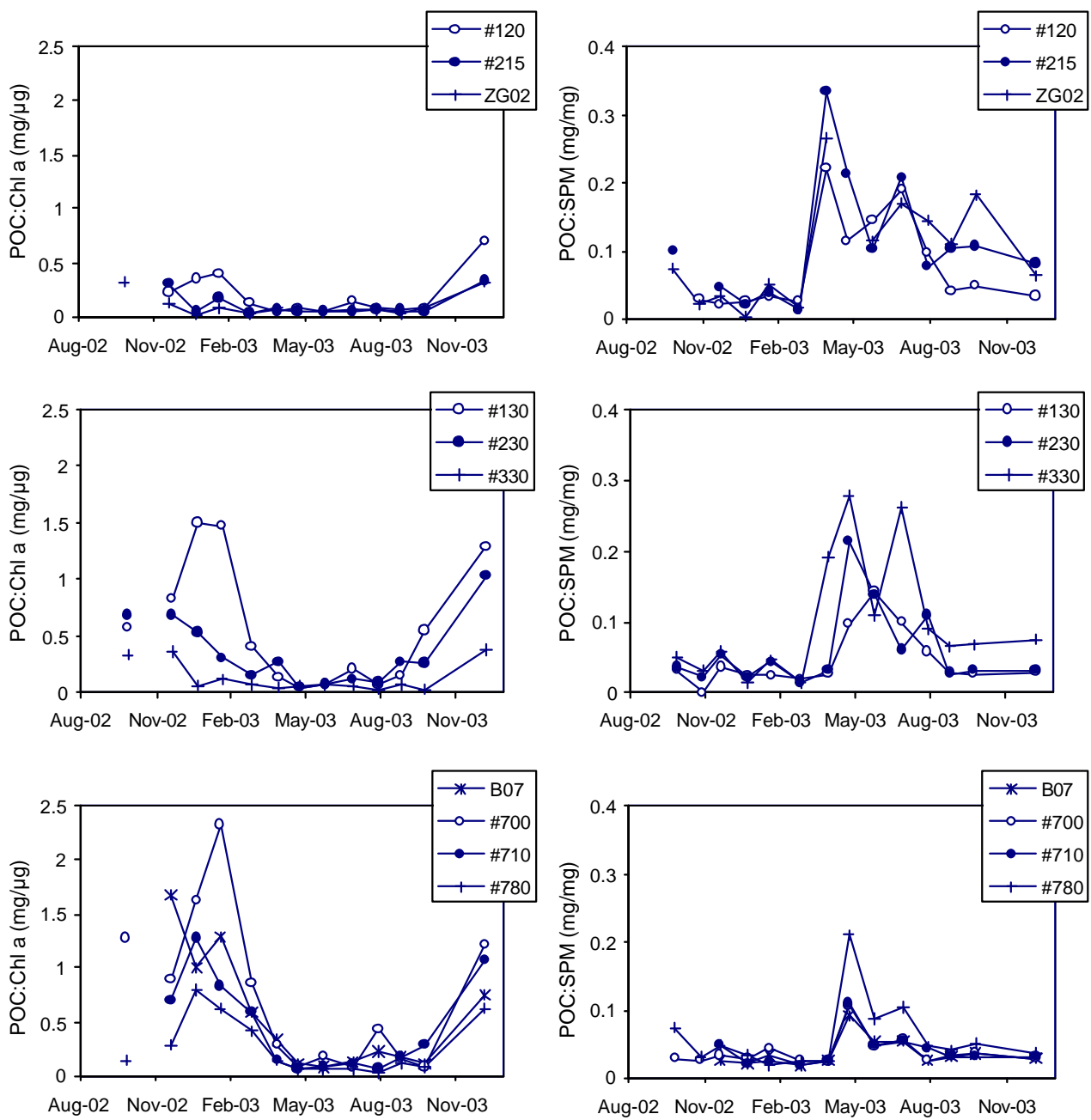

Fig. 3. Seasonal trend in the ratios of POC:Chl $a$ and POC:SPM for the ten stations investigated. The stations are grouped per transect: on the Nieuwpoort transect stations 120, 215 and ZG02, on the Oostende transect stations 130, 230 and 330 and on the Scheldt transect stations B07, 700, 710 and 780 .

\section{Results}

\subsection{Chlorophyll $a$, POC and DOC}

The chlorophyll $a$ concentration was low from September 2002 until February 2003 after which it increased at all stations (Fig. 2). The highest concentrations in chlorophyll $a$ were observed during the cruises at the end of March and April 2003. The chlorophyll $a$ concentration remained at a higher level from May to September 2003 as compared to the values from September 2002 to February 2003. Finally, the chlorophyll $a$ concentration returned to a lower level in December 2003. No data are available between September 2003 and December 2003.

The POC concentration did not show a clear seasonal trend except for the deep stations (Fig. 2). The highest concentrations were found at the shallow stations B07 and 700 close to the mouth of the Scheldt. The seasonal trends in POC and chlorophyll $a$ concentrations were most similar at three deeper stations $(215, \mathrm{ZG02}, 330)$. These observations suggest that resuspended sediment is an important contribution to the POC concentration. Figure 3 shows that in winter the high POC:Chl $a$ ratio is accompanied by the low POC:SPM ratio, suggesting a greater contribution of resuspended sediment to the POC concentration during this period. The low POC:Chl $a$ ratio and high POC:SPM ratio observed in spring and summer indicate that phytoplankton is the dominant contribution to the POC concentration (Fig. 3). The POC: Chl

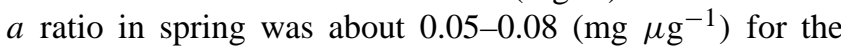
stations on the Nieuwpoort and Oostende transects, which is typical for phytoplankton (Abril et al., 2002 and references therein). A slightly higher POC:Chl $a$ ratio of 0.07 $0.11\left(\mathrm{mg} \mu \mathrm{g}^{-1}\right)$ was recorded for the stations on the Scheldt transect. The relatively high POC:Chl $a$ maximal values and the relatively low POC:SPM maximal values at the stations 

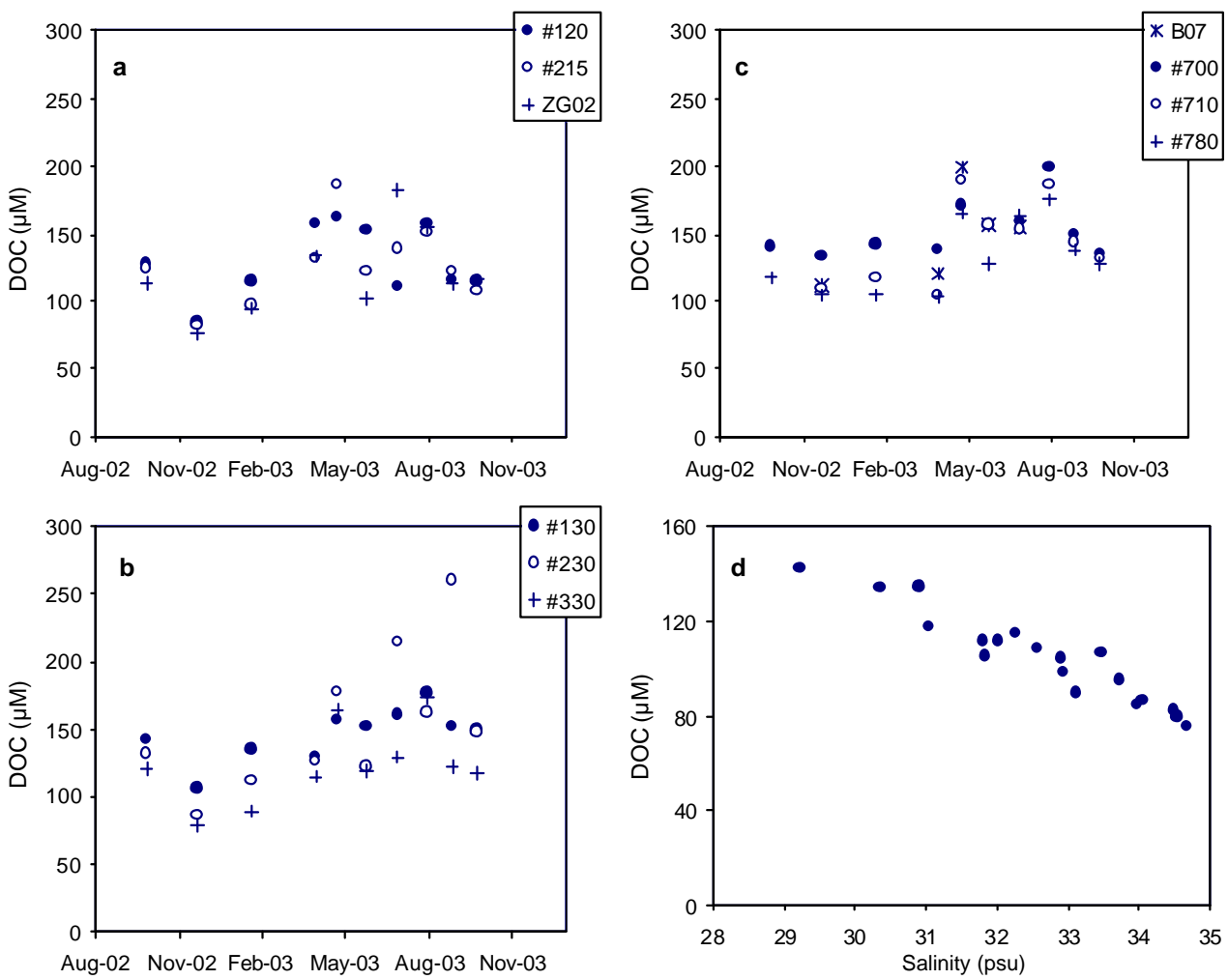

Fig. 4. Seasonal trend in the DOC concentration for the stations, (a) on the Nieuwpoort transect, (b) on the Oostende transect and (c) on the Scheldt transect. (d) The DOC concentration versus salinity plot for the months of November 2002 and January 2003.

along the Scheldt transect, as compared to the stations along the Nieuwpoort transect, indicate that the contribution of resuspended sediment to the SPM is more important at the stations located close to the mouth of the estuary.

The seasonal evolution in the DOC values follows the classical trend with minimal values in winter and elevated values during spring-summer (Fig. 4a, b, c). The DOC concentration exhibits an increasing trend from its minimum in November 2002 until April 2003, remaining elevated from April to July 2003, after which it again decreased. Figure 4d indicates that the winter DOC values (November 2002 and January 2003) correlate well with salinity $\left(\mathrm{R}^{2}=0.91, \mathrm{n}=19\right)$.

\subsection{Dissolved Si and N species}

The seasonal pattern in the silicate concentration showed the same trend for all stations (Fig. 5). The silicate concentration was the highest in the months of January and February, and reached its lowest values in May. Two general trends can be observed. First, the maximal silicate concentrations observed in winter are higher at the stations on the Scheldt transect close to the mouth of the estuary (700, 710, 780 and B07; 35-48 $\left.\mu \mathrm{M} \mathrm{Si}(\mathrm{OH})_{4}\right)$, than those of the Nieuwpoort transect $\left(120,215, \mathrm{ZG} 02 ; 10-28 \mu \mathrm{M} \mathrm{Si}(\mathrm{OH})_{4}\right)$, the most southwestern transect. The maximal silicate values at the stations of the Oostende transect (130, 230 and 330) are intermediate (17- $\left.39 \mu \mathrm{M} \mathrm{Si}(\mathrm{OH})_{4}\right)$. Secondly, the dissolved silicate concentration decreases going from the near-shore to the offshore stations along each transect.

Nitrate is the predominant dissolved nitrogen species of the four $\mathrm{N}$ species measured. The nitrate plus nitrite (hereafter referred to as nitrate) concentration at all stations increased after October 2002 and remained high from December 2002 to February/March 2003 after which it reached its lowest values in May 2003 (Fig. 5). Similar to the silicate concentration, the maximal nitrate concentrations are higher at stations located close to the mouth of the Scheldt estuary as compared to those along the Nieuwpoort transect. Along each transect, a trend of decreasing nitrate concentration from the coast seaward is also apparent. The variation in the ammonium concentration with time is less pronounced than for nitrate, but again a minimum in the concentration occurs around April-May 2003 (Fig. 6). Differences in ammonium concentration between the stations are much less distinct than for the silicate and nitrate data. The DON concentrations are the highest in winter and start to decrease after March 2003 until they reach their minimum in July (Fig. 6). The DON seasonal patterns for the stations on the same transect are very similar.

The dissolved silicate, nitrate and ammonium concentrations in the winter months (November and December 2002, 

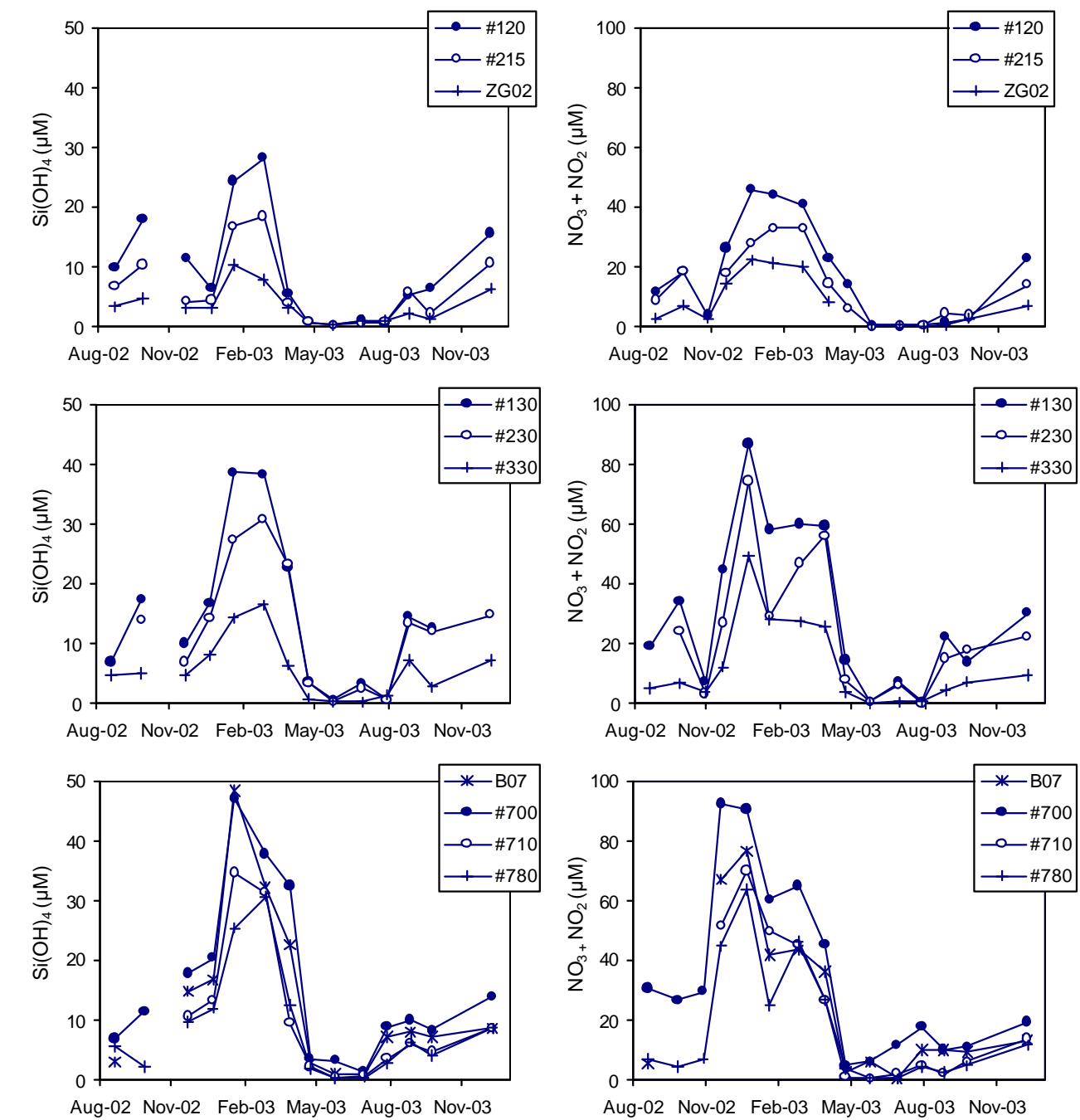

Fig. 5. Seasonal trend in the concentrations of silicate and nitrate for the stations on the Nieuwpoort transect (120, 215 and ZG02), on the Oostende transect (130, 230 and 330) and on the Scheldt transect (B07, 700, 710 and 780).

and January, February and December 2003) have been plotted against salinity (Fig. 7). Within the same month, the differences in silicate and nitrate concentrations between stations can be largely explained by differences in salinity. But differences exist between the winter months, which could be attributed to variations in river discharges. The ammonium concentration correlated with salinity only in January 2003 and not during any other winter month (Fig. 7), showing the non-conservative behaviour of this nutrient. DON versus salinity plot (Fig. 7) shows a weak correlation between these two parameters for January and March 2003 samples $\left(\mathrm{R}^{2}=0.45, \mathrm{n}=19\right)$.

\subsection{Phosphorus species}

Three dissolved $\mathrm{P}$ species were determined: phosphate $\left(\mathrm{PO}_{4}\right)$, polyphosphates and dissolved organic phosphorus (DOP). The polyphosphate concentration was always very low, generally less than $0.11 \mu \mathrm{M}$, and did not show any seasonal or spatial variation (data not shown). The seasonal pattern of the DOP concentration appears to exhibit two maxima: one around May 2003 and a second one at a higher concentration around August-September 2003 (Fig. 8a, b). The DOP concentration was similar for all stations and was usually low compared to the $\mathrm{PO}_{4}$ concentration, although the DOP concentration exceeded the $\mathrm{PO}_{4}$ concentration at all stations in the months of April and May 2003. The $\mathrm{PO}_{4}$ concentration at the different stations shows a decreasing trend along a transect going from the coast to the open sea (Fig. 8a, b). However, the differences in concentration are not as pronounced as observed for the silicate and the nitrate concentrations. At the stations of the Nieuwpoort transect (120, 215 and ZG02) and station 330, the strongest decline in $\mathrm{PO}_{4}$ concentrations was observed between February and March 2003, whereas the other stations showed a strong decline between 


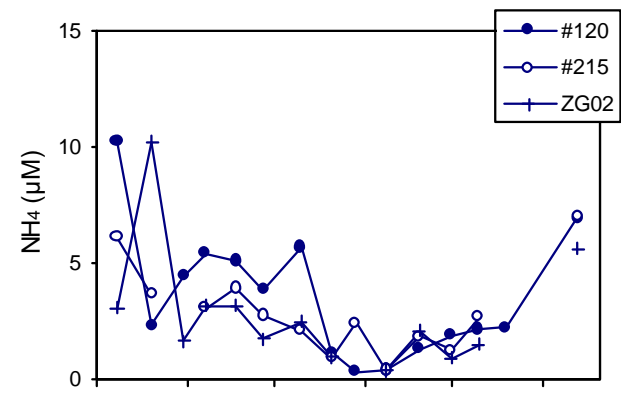

Aug-02 Nov-02 Feb-03 May-03 Aug-03 Nov-03
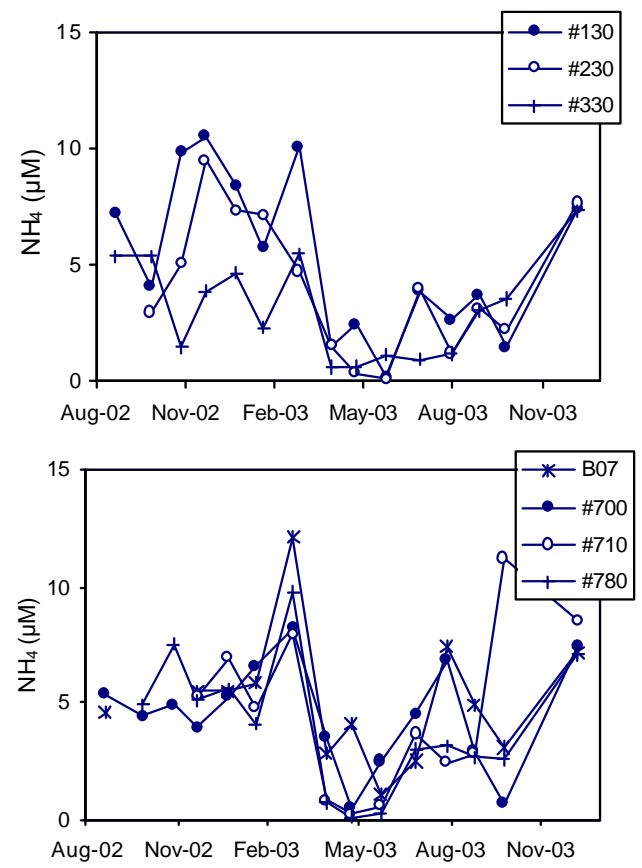
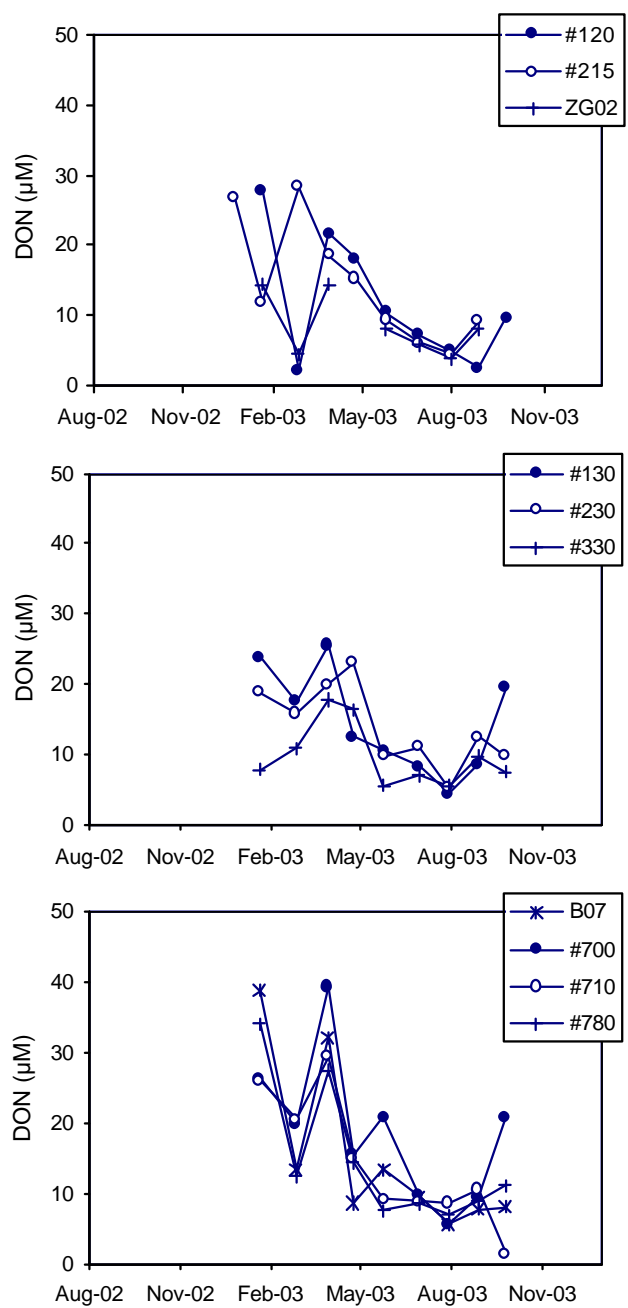

Fig. 6. Seasonal trend in the concentrations of ammonium and dissolved organic nitrogen (DON) for the stations on the Nieuwpoort transect (120, 215 and ZG02), on the Oostende transect (130, 230 and 330) and on the Scheldt transect (B07, 700, 710 and 780).

March and April 2003. The lowest values for the $\mathrm{PO}_{4}$ concentration were measured in April at the following stations: $120,130,700,710,780$ and $\mathrm{B} 07$, whereas the lowest values at stations 215, 230 and 330 were measured in May 2003. No data are available for station ZG02 in April 2003. At most stations, the $\mathrm{PO}_{4}$ concentrations increase from August onwards reaching the winter values again in the fall. This seasonal pattern was not observed for silicate and nitrate.

The corrected POP concentration, as calculated in Sect. 2.4, was highest in April 2003 for all stations, with the exceptions of station ZG02 that was not sampled during this month and of station 700 that exhibits two additional and higher peaks in corrected POP concentration in January and July 2003 (Fig. 8a, b). The corrected POP and POC concentrations are correlated $\left(\mathrm{R}^{2}=0.52\right)$, as well as the POP content and POC:SPM ratio $\left(\mathrm{R}^{2}=0.67\right)$. In general, the corrected $\mathrm{POP}$ concentrations are elevated in spring and summer when the $\mathrm{PO}_{4}$ concentrations are low. The seasonal trends of the corrected POP concentration and the POP content are similar (data not shown). The highest values of POP content are observed at the stations further away from the mouth of the Scheldt estuary. The PIP contents at the stations of the Scheldt transect are very similar to those of POP as well as the seasonal trend (data not shown). However, at the stations of the other two transects the PIP content is similar to the POP content in the winter, but PIP content does not increase in spring as the POP content does.

The relative concentrations of $\mathrm{PO}_{4}$, DOP, uncorrected POP and PIP for station 330 are plotted in order to visually summarise the seasonal transformations between dissolved vs. particulate and organic vs. inorganic phosphorus phases (Fig. 9).

The winter phosphate concentration correlated with salinity, in contrast to the spring and summer values (Fig. 10). In February 2003, the phosphate concentration was depressed somewhat in the lower salinity range, decreasing further in 

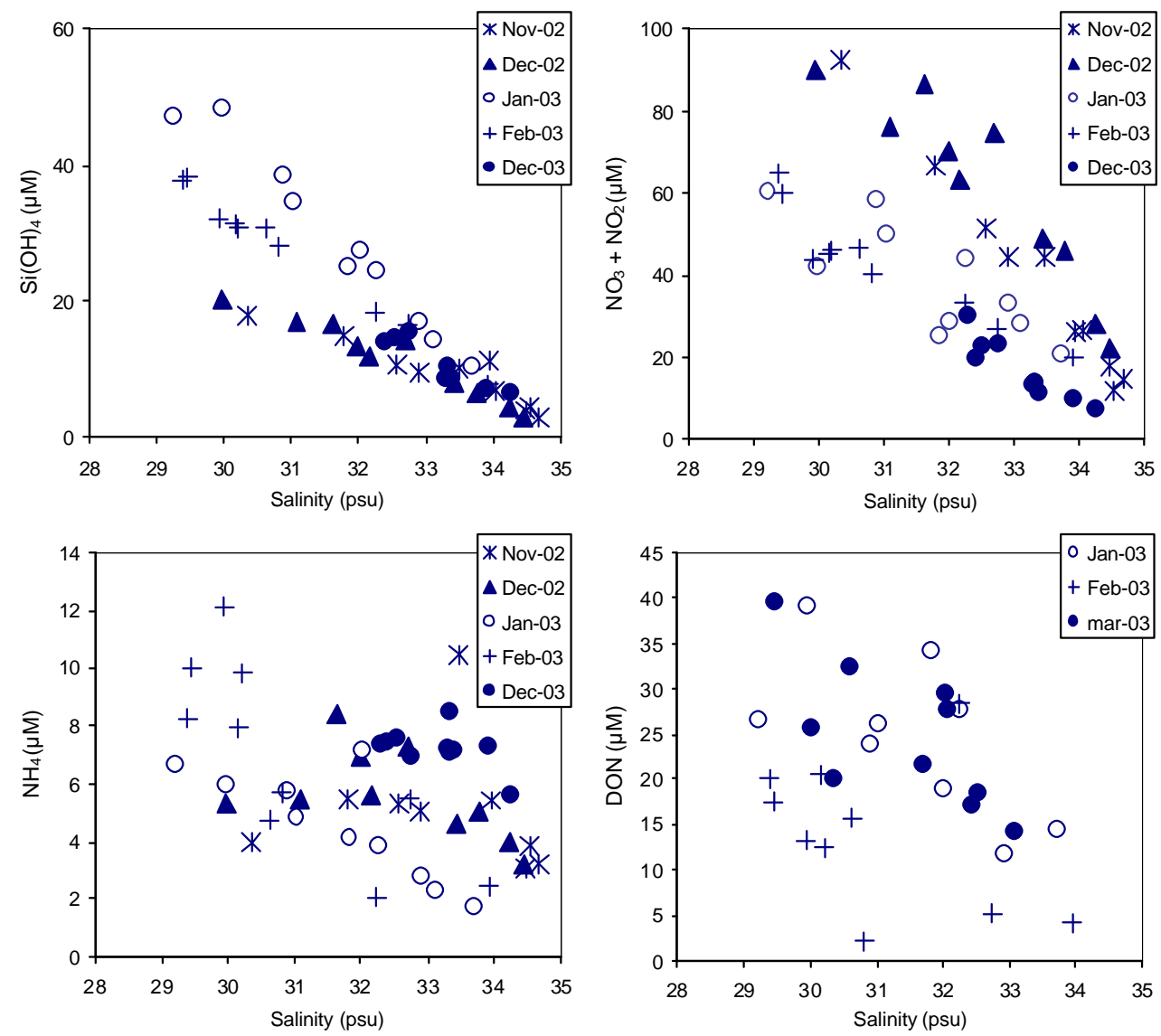

Fig. 7. Dissolved silicate, nitrate and ammonium concentrations versus salinity in the winter months (November and December 2002 and January, February and December 2003). The DON concentration versus salinity in the months of January, February and March 2003.

spring. The DOP concentration was generally lower in winter than in spring and summer, and was never correlated with the salinity (Fig. 10).

\section{Discussion}

\subsection{Spatial trends}

The spatial distributions of the major nutrients in the Belgian coastal zone result from the mixing of relatively low nutrient-high salinity North Atlantic water flowing northeastward through the Channel into the North Sea with high nutrient freshwater which is discharged from the rivers Rhine, Meuse and Scheldt. The freshwater flows clockwise southwestward along the southernmost part of the Dutch (south of the mouth of the Rhine) and Belgian coasts, before it mixes with the northeastward flowing Channel water (van Bennekom and Wetsteyn, 1990; Lacroix et al., 2004). This water circulation pattern is reflected in the winter nutrient concentrations at the different stations: high nutrient concentrations at the stations on the Scheldt transect as well as the coastal stations 120 and 130, which are located in the
Rhine/Meuse and Scheldt plumes and lower nutrient concentrations at the other stations. Basically, this pattern creates a winter nutrient gradient in the nearshore-offshore direction and in the northeast-southwest direction. The influence of riverine nutrient input was also apparent from the DOC, nitrate, silicate and phosphate versus salinity plots in winter (Figs. 4, 7 and 10). The extrapolation of the winter DOC plot to zero-salinity gives a value of $499 \mu \mathrm{M}$, which is typical of the Scheldt river endmember (461-538 $\mu \mathrm{M}$, unpublished results; $567 \mu \mathrm{M}$, Abril et al., 2002). DOC values at zero-salinity in the Rhine are typically half of those of the Scheldt ( $242 \mu \mathrm{M}$, Abril et al., 2002). Extrapolation of the winter nitrate and silicate concentrations versus salinity plot results in river values of $235 \mu \mathrm{M} \mathrm{Si}(\mathrm{OH})_{4}$ and $353 \mu \mathrm{M}$ $\mathrm{NO}_{3}$ at zero salinity. These values do not compare well with the winter values in the Rhine at Maassluis, which were $119 \mu \mathrm{M} \mathrm{Si}(\mathrm{OH})_{4}$ and $214 \mu \mathrm{M} \mathrm{NO}_{3}$ in 2003 (RWS). For the Scheldt on the other hand, higher concentrations of $344 \mu \mathrm{M}$ $\mathrm{NO}_{3}$ were measured near Antwerp in winter 2003 (average of January, February, November and December). Silicate concentrations measured in March 2003 along a longitudinal transect on the Scheldt showed a conservative behaviour of 

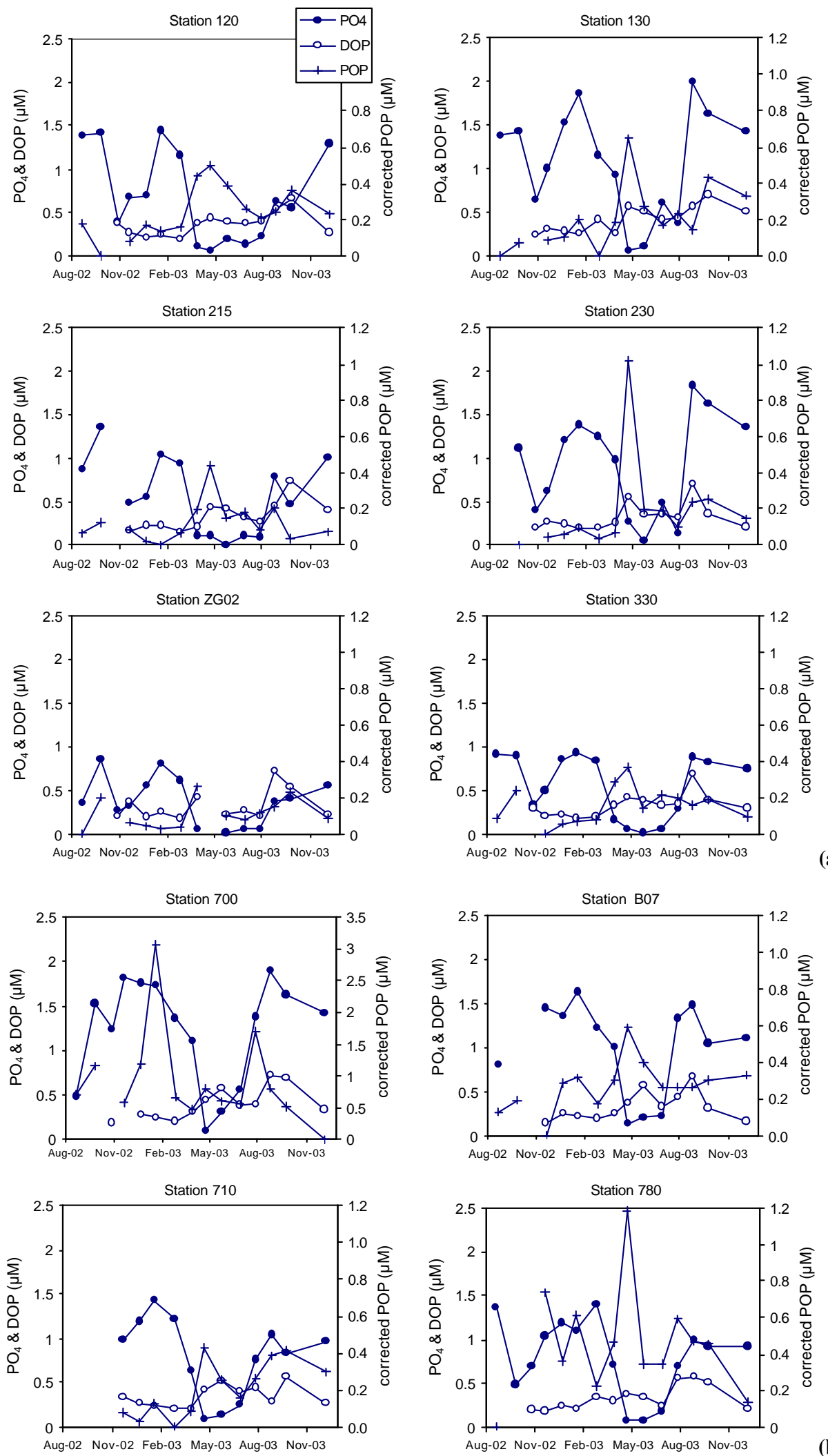

(b)

Fig. 8. (a) Seasonal trends in the $\mathrm{PO}_{4}$, DOP and corrected POP concentrations for the Nieuwpoort transect (120, 215 and ZG02) and Oostende transect (130, 230 and 330). (b) Seasonal trends in the $\mathrm{PO}_{4}$, DOP and corrected POP concentrations for the Scheldt transect (B07, 700, 710 and 780). Please note the different scale for the corrected POP concentration of station 700. 
silicate and a zero-salinity concentration of $211 \mu \mathrm{M} \mathrm{Si}(\mathrm{OH})_{4}$ was measured (V. Carbonnel, personal communication). The Scheldt DOC, nitrate and silicate values agree very well with extrapolated values from the Belgian coastal zone nutrientsalinity plots. Based on these observations, we conclude that the influence of the Rhine water in the Belgian coastal zone on the winter DOC, nitrate and silicate concentrations could not be detected in our study. The extrapolation of the phosphate winter concentration versus salinity yields a zero salinity phosphate concentration of $7.6 \mu \mathrm{M}$. The difference in the concentration between the two river endmembers is not so large for $\mathrm{PO}_{4}$ as those found for DOC, nitrate and silicate. However, phosphate concentrations of $6.6 \mu \mathrm{M}$ were recorded for the Scheldt at Temse and lower values of about $4.0 \mu \mathrm{M}$ for the Rhine (unpublished results).

The lack of a spatial trend in the DOP concentration and the lack of a correlation with salinity at any time of the year suggests that DOP is produced at sea in the Belgian coastal zone (Figs. 8 and 10). The DON and DOP versus salinity trends are not the same (Figs. 7 and 10). For DON a correlation existed with salinity in the months of January and March 2003, implying that in contrast to the DOP riverine input may be a source of DON for the Belgian coastal zone. The extrapolated zero-salinity DON concentration of $157 \mu \mathrm{M}$ might be high, although Dafner et al. (1999) reported a DON concentration of $110 \mu \mathrm{M}$ downstream of Antwerp. Traditionally one would expect maximal DON concentrations during summer and minimal values during winter (e.g. Butler et al., 1979). The difference between the seasonal patterns of DON found in this study and that of Butler et al. (1979) may be explained by the fact that the Scheldt is heavily polluted especially with respect to nitrogen, whereas the western English Channel was not between 1969 and 1977.

The timing of the spring bloom, as reflected by the chlorophyll $a$ data (Fig. 2), seems to be evenly distributed over the Belgian coastal zone. There are two pronounced peak values, at station 230 and station B07 at the end of April 2003. General trends as seen in the nutrient distribution, however, are not apparent for chlorophyll $a$ in our data set. Sampling was conducted once a month, too low a frequency to discern patterns in the phytoplankton bloom between stations, such as in the exact timing and intensity of the bloom. The spatial distribution of the particulate organic carbon (Fig. 3) and phosphorus (not shown) contents indicates an increasing trend going from the northeast to the southwest. This trend is caused by the dilution of organic-rich pelagic material with relatively organic-poor resuspended sediment at the more turbid stations near the mouth of the Scheldt estuary as was demonstrated in Sect. 3.1.

\subsection{Seasonal trends in phosphate concentration}

Besides the minimum in $\mathrm{PO}_{4}$ concentration in spring, another minimum was observed in October 2002, which was not accompanied by an increase in corrected POP or chloro-

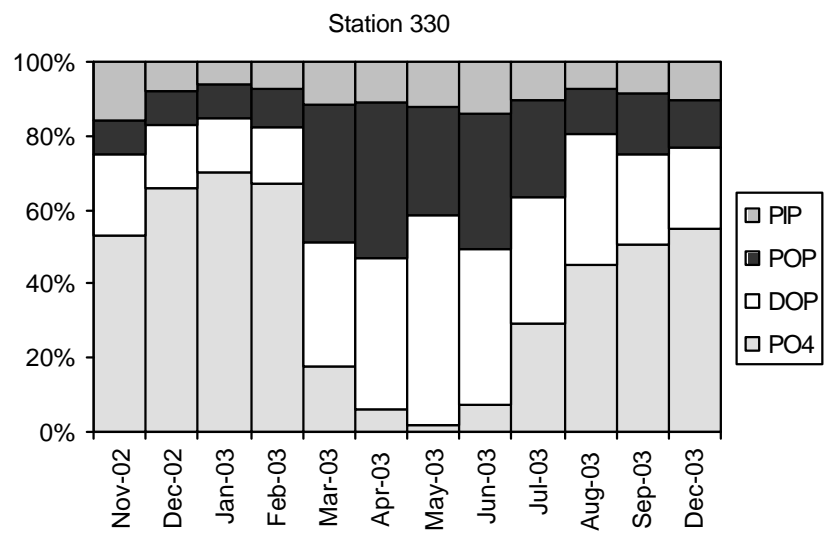

Fig. 9. Relative contributions of $\mathrm{PO}_{4}$, DOP, POP and PIP to the total $\mathrm{P}$ for station 330 .

phyll $a$ concentration. This latter minimum was caused by the increased contribution of high salinity-low nutrient water from the Channel. Phosphate concentration versus salinity plots for the different months indicate a more or less conservative behaviour in the winter months (October 2002, November 2002, December 2002, January 2003 and December 2003), whereas biological activity determines the phosphate concentration in spring-summer and summer-fall (Fig. 10).

The largest decrease in the major nutrient concentrations occurs between the end of February and the end of April 2003 (Figs. 5 and 8) coinciding with the largest increase in chlorophyll $a$ concentration (Fig. 2). It also corresponds to an increase in POC:SPM, a decrease in POC:Chl $a$ ratios (Fig. 3), and an increase in corrected POP concentration (Fig. 8). For the northeastern stations (700, 710, 780, B07, 130 and 230) the largest decline in nutrients occurs between the end of March and the end of April 2003, whereas for the southwestern stations the major decrease occurs one month earlier. This is consistent with the findings of Gonzales (unpublished results); the spring bloom was initiated in the southwest in late February 2003 and had spread towards the northeast by the end of April (MIDAS). Spatial and temporal patterns in oxygen saturation, $\mathrm{pCO}_{2}$ and chlorophyll $a$ concentration in the Belgian coastal zone described by Borges and Frankignoulle (2002) match these observations. The timing of the spring bloom initiation could be related to light conditions due to the spatial distribution of the SPM. At the end of the summer, the dissolved $\mathrm{Si}, \mathrm{PO}_{4}$ and DIN concentrations increase again when their supply exceeds their consumption. In contrast to the dissolved Si and DIN, the $\mathrm{PO}_{4}$ concentrations have already reached their prebloom levels by the fall. This difference in the seasonal evolution of $\mathrm{P}$ versus $\mathrm{N}$ and $\mathrm{Si}$ was also noted in a compilation of nutrient data from 1993-2000 in the same area (De Galan et al., 2004). Thus, the rate of regeneration and/or supply of phosphorus is higher than that for dissolved Si and DIN 

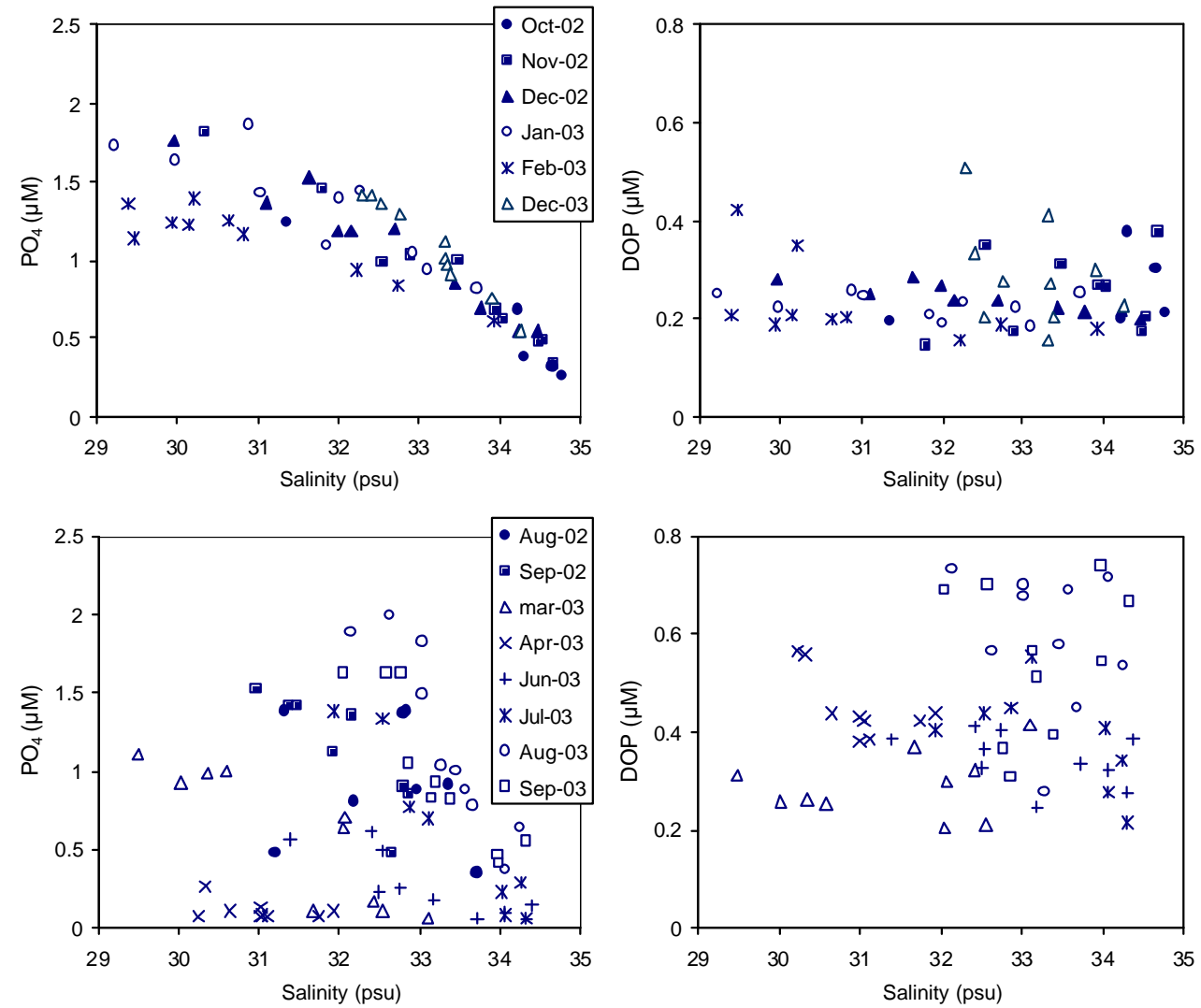

Fig. 10. $\mathrm{PO}_{4}$ and DOP concentrations versus salinity, data of all the stations in different months. For the month of May, no salinity data were available. DOP was not determined for the months of August and September 2002.

in the Belgian coastal zone. One source of these nutrients is river run-off from the Rhine/Meuse and Scheldt. In 2003, the nitrate to phosphate ratio in the Rhine at Maassluis varied between 27 and 243 (RWS) and between 40 and 249 in the Scheldt at Antwerp (unpublished results). These ratios indicate that there was always more nitrate delivered to the Belgian coastal zone than phosphate (ratio $>16$ ). Another source for nitrogen is atmospheric input, but for phosphorus this is negligible in the North Sea (Brion et al., 2004). Both atmospheric and riverine input would deliver more nitrogen than phosphorus and are therefore not likely to cause the earlier replenishment of phosphate as compared to nitrate in the Belgian coastal zone. In the Southern Bight of the North Sea, the oceanic/riverine inflow rates of phosphate, nitrate and silicate are insufficient to support their seasonal cycle and therefore internal recycling is required (Prandle et al., 1997). Since the supply of phosphate to the Belgian coastal zone is not higher than that of silicate and nitrate, the difference can be attributed to the internal cycling. Preferential regeneration of $\mathrm{P}$ over $\mathrm{N}$ and $\mathrm{C}$ has already been demonstrated both in the hydrolysis of dissolved organic matter (e.g. Hopkinson et al., 1997; Clark et al., 1998; Vidal et al., 1999) and in the remineralisation of particulate organic matter (Bishop et al.,
1977; Garber, 1984; Martin et al., 1987). Alternatively, the loss of nitrate via denitrification to the atmosphere and the buffering of phosphate via sorption on suspended matter or the sediment might also play a role.

\subsection{Phosphate being the first limiting nutrient}

Typical nitrate and phosphate half saturation constants for coastal phytoplankton populations are around 1-2 $\mu \mathrm{M}$ and $0.1-0.5 \mu \mathrm{M}$, respectively, and typical silicate half saturation constants for coastal diatom populations are around $1-2 \mu \mathrm{M}$ (Fisher et al., 1988). In our study area, the lowest nutrient concentrations recorded for the individual stations range from $<0.01$ to $0.13 \mu \mathrm{M}$ for $\mathrm{PO}_{4}$, from 0.27 to $1.53 \mu \mathrm{M}$ for $\mathrm{Si}(\mathrm{OH})_{4}$ and from 0.37 to $5.48 \mu \mathrm{M}$ for $\mathrm{NO}_{3}$. The first nutrient to drop below its half saturation constant is phosphate, then silicate and later nitrate, although not at all stations.

Table 2 attempts to indicate possible limiting nutrients for phytoplankton growth. The concentrations of $\Sigma$ DIN, phosphate and silicate are given in the months when they are lowest for individual stations. For some stations, all three nutrients reach their lowest levels in the same month; then only the data of that month are listed and the N:P, Si:P and $\mathrm{Si}: \mathrm{N}$ ratios are given. When $\mathrm{N}: \mathrm{P}$ and $\mathrm{Si}: \mathrm{P}$ are larger than 
Table 2. Lowest nutrient concentrations observed (in bold), N:P, Si:P and Si:N ratios and possible limiting nutrient for each station.

\begin{tabular}{|c|c|c|c|c|c|c|c|c|}
\hline Station & Date & $\begin{array}{l}\Sigma \mathrm{DIN} \\
(\mu \mathrm{M})\end{array}$ & $\begin{array}{l}\text { DIP } \\
(\mu \mathrm{M})\end{array}$ & $\begin{array}{l}\mathrm{Si} \\
(\mu \mathrm{M})\end{array}$ & $\begin{array}{l}\mathrm{N}: \mathrm{P} \\
\text { Ratio }\end{array}$ & $\begin{array}{l}\mathrm{Si}: \mathrm{P} \\
\text { Ratio }\end{array}$ & $\begin{array}{l}\mathrm{Si}: \mathrm{N} \\
\text { Ratio }\end{array}$ & $\begin{array}{l}\text { Limiting } \\
\text { Nutrient }\end{array}$ \\
\hline \multirow{2}{*}{120} & Apr. 2003 & 14.05 & 0.07 & 0.92 & 211 & 14 & 0.1 & $\mathrm{Si}(\mathrm{P}) *$ \\
\hline & May 2003 & 0.78 & 0.19 & 0.41 & 4 & 2 & 0.5 & $\mathrm{Si}$ \\
\hline 215 & May 2003 & 0.66 & $<0.01$ & 0.36 & $>66$ & $>36$ & 0.5 & $\mathrm{P}$ \\
\hline ZG02 & May 2003 & 0.73 & 0.02 & 0.36 & 35 & 17 & 0.5 & $\mathrm{P}$ \\
\hline \multirow{2}{*}{130} & Apr. 2003 & 16.87 & 0.07 & 3.63 & 253 & 54 & 0.2 & $\mathrm{P}$ \\
\hline & May 2003 & 0.60 & 0.10 & 0.46 & 6 & 5 & 0.8 & $\mathrm{Si}$ \\
\hline 230 & May 2003 & 0.37 & 0.04 & 0.36 & 9 & 9 & 1.0 & $?$ \\
\hline 330 & May 2003 & 1.31 & 0.01 & 0.27 & 116 & 24 & 0.2 & $\mathrm{P}$ \\
\hline \multirow{2}{*}{700} & Apr. 2003 & 5.48 & 0.10 & 3.72 & 53 & 36 & 0.7 & $\mathrm{P}$ \\
\hline & June 2003 & 16.37 & 0.57 & 1.53 & 29 & 3 & 0.1 & $\mathrm{Si}$ \\
\hline \multirow{2}{*}{710} & Apr. 2003 & 1.51 & 0.09 & 2.27 & 18 & 27 & 1.5 & $\mathrm{P}$ \\
\hline & May 2003 & 1.15 & 0.13 & 0.55 & 9 & 4 & 0.5 & $\mathrm{Si}$ \\
\hline \multirow{2}{*}{780} & Apr. 2003 & 3.76 & 0.08 & 1.95 & 50 & 26 & 0.5 & $\mathrm{P}$ \\
\hline & May 2003 & 0.92 & 0.08 & 0.36 & 11 & 4 & 0.4 & $\mathrm{Si}$ \\
\hline \multirow{2}{*}{ B07 } & Apr. 2003 & 6.85 & 0.13 & 2.79 & 52 & 21 & 0.4 & $\mathrm{P}$ \\
\hline & June 2003 & 3.30 & 0.23 & 1.06 & 14 & 5 & 0.3 & $\mathrm{Si}$ \\
\hline
\end{tabular}

* Because Si can only be a limiting nutrient for diatoms, the limiting nutrient for Phaeocystis is indicated in brackets (P).

16, phosphate is likely to be the limiting nutrient. In the case where $\mathrm{Si}: \mathrm{P}<16$ and $\mathrm{Si}: \mathrm{N}<1$, then silicate is likely to be the limiting nutrient (for diatom growth). When $\mathrm{N}: \mathrm{P}<16$ and $\mathrm{Si}: \mathrm{N}>1$, nitrogen would be the limiting element. Note that for the four stations near the mouth of the estuary (700, 710, 780 and B07) and station 130, the phytoplankton is first P-limited but then becomes Si-limited. The stations that are least influenced by the river plumes (ZG02 and 330) are likely to be P-limited for phytoplankton growth. Phosphorus limitation of primary production during the early spring bloom was also observed in the Gironde plume (Herbland et al., 1998; Labry et al., 2002), whereas the winter bloom was initiated by light availability (Labry et al., 2001). Pigment analyses and microscopic cell counts conducted on water samples obtained during the same cruises show that the phytoplankton community was dominated by diatoms, except in April 2003 (R. Gonzales, unpublished results). The contribution of Phaeocystis to the total chlorophyll $a$ was larger than 50\% in April 2003 for all stations except station ZG02, which was not sampled in April, and station 700 (35\%; R. Gonzales, unpublished results). At station 120, Si was indicated as limiting nutrient in April 2003 (Table 2). However, as Si can only be a limiting nutrient for diatoms and Phaeocystis dominates the phytoplankton community, the limiting nutrient for non-diatom species would be $\mathrm{P}$ as indicated in brackets. During the cruise in late May 2003, diatoms were again the dominant species. At no time is the phytoplank- ton community limited by inorganic nitrogen in the Belgian coastal zone. When the N:P ratios are calculated using total dissolved $\mathrm{N}$ and $\mathrm{P}$ concentrations, i.e. including dissolved organic nitrogen and phosphorus, $\mathrm{P}$ is limiting. This is because the DON concentration is more than 16 times that of DOP in the months considered. DON always constitutes a large fraction of the total dissolved nitrogen, in contrast to DOP, which becomes an important fraction only when the phosphate levels are low. De Galan et al. (2004) also reported that DON represents a major fraction of the total dissolved nitrogen, but a seasonal trend in the DON concentrations was not observed, possibly due to a too low sampling frequency.

\subsection{DOP and phosphorus cycling}

When the $\mathrm{PO}_{4}$ concentration is low, DOP is an important source of biologically available phosphorus for both bacteria and phytoplankton in marine ecosystems (Orrett and Karl, 1987; Björkman and Karl, 1994). DOP is not readily available to phytoplankton and bacteria, but it can be utilized as a phosphorus source by means of hydrolytic enzymes: the non-specific alkaline phosphatase (Perry, 1972) and 5'-nucleotidase (Ammerman and Azam, 1985; Flynn et al., 1986). Alkaline phosphatase is induced by low $\mathrm{PO}_{4}$ concentrations and cleaves the $-\mathrm{PO}_{4}$ moiety from organic phosphorus compounds after which the cell can assimilate the $\mathrm{PO}_{4}$. Van Boekel and Veldhuis (1990) have shown that alkaline phosphatase synthesis in Phaeocystis sp. is controlled 
by the external phosphate concentration and that the threshold concentration for derepression is around $0.5 \mu \mathrm{M}$. Unlike alkaline phosphatase, $5^{\prime}$-nucleotidase recognizes the carbon moiety of nucleotides and is not inhibited at high $\mathrm{PO}_{4}$ levels.

The winter DOP concentrations in the Belgian coastal zone (Fig. 10) are comparable to those reported for the oligotrophic North Pacific Subtropical Gyre $(\sim 0.2 \mu \mathrm{M}$; Church et al., 2002), the oligotrophic central Atlantic Ocean (0.1$0.3 \mu \mathrm{M}$; Vidal et al., 1999) and the northeastern continental shelf of the USA ( $\sim 0.2 \mu \mathrm{M}$; Hopkinson et al., 1997). The elevated DOP concentrations in the Belgian coastal zone are of similar magnitude to those reported for surface waters along the north coast of Australia (Mulholland et al., 2002) and the Southern California Bight (Ammerman and Azam, 1991). DOP concentrations of $\sim 0.2 \mu \mathrm{M}$ are reported for the Baltic Sea, but higher DOP values of $0.35-0.75 \mu \mathrm{M}$ were measured in cyanobacterial blooms (Nausch et al., 2004). The seasonal pattern of DOP (monthly averages from 1969 to 1977) in the Channel shows winter concentrations of $0.14-0.18 \mu \mathrm{M}$ and elevated concentrations of $0.20-0.28 \mu \mathrm{M}$ from April to August (Butler et al., 1979).

When the $\mathrm{PO}_{4}$ concentration is low, a significant fraction of the dissolved $\mathrm{P}$ is present in the form of DOP. Between March and July, when the $\mathrm{PO}_{4}$ concentration is lowest (Fig. 8), phytoplankton and bacteria may have to turn to DOP as their phosphorus source. In general, it is assumed that elevated dissolved organic matter (DOM) concentrations in surface waters result from enhanced DOM production associated with primary production (Duursma, 1961). This may be due to DOM excretion from cells (Lancelot, 1979), viral mediated cell lysis (Furhman and Shuttle, 1993), sloppy feeding by zooplankton (Eppley et al., 1981) or from particle solubilization (Smith et al., 1992). The seasonal trend in DOP shows two periods of elevated concentrations (Fig. 8). The first period is in April for the most southwestern stations and in May for the most northeastern stations. This period of elevated DOP concentration coincides with the lowest $\mathrm{PO}_{4}$ concentration and the highest chlorophyll $a$ and corrected POP concentration, and therefore most likely corresponds to the period of elevated primary production. The second period of elevated DOP concentration occurs in August-September when the corrected POP concentration and the POP content have decreased strongly and the $\mathrm{PO}_{4}$ concentration has increased again. In this period, the organic phosphorus contained in cells is released upon their lysis and degraded, and the DOP is presumably further remineralised into phosphate. Turk et al. (1992) have demonstrated that bacterial biomass grazed by protozoa plays an important role in the cycling of $\mathrm{P}$, due to the ejection of the consumed bacterial DNA and the subsequent rapid DNA degradation and liberation of $\mathrm{PO}_{4}$. Thus, the elevated DOP concentrations indicate the start of two distinct and consecutive periods of intensive $P$ cycling. During the first period $\mathrm{P}$ is regenerated and sustains the bloom, and during the second period $\mathrm{P}$ is recycled as biomass is decaying.

\section{Conclusions}

Nutrient and $\mathrm{P}$ speciation data obtained by monthly cruises during one complete year were presented for 10 stations in Belgian coastal zone, and spatial and seasonal trends were studied. The river Scheldt has a strong influence on the distribution of inorganic nutrients, DOC and possibly DON, but not on that of the DOP.

At most of the stations studied, $\mathrm{PO}_{4}$ is the first nutrient to decrease below its half-saturation value during the bloom period, thereafter $\mathrm{Si}(\mathrm{OH})_{4}$ and subsequently $\mathrm{NO}_{3}$. The elemental ratios of $\mathrm{N}, \mathrm{P}$ and $\mathrm{Si}$ suggest that either $\mathrm{P}$ - or $\mathrm{Si}$-limitation of phytoplankton growth could develop, and that at the stations on the Scheldt transect, P-limitation is followed by $\mathrm{Si}$ limitation. The rate of regeneration of $\mathrm{PO}_{4}$ is much faster than that of $\mathrm{NO}_{3}$ and $\mathrm{Si}(\mathrm{OH})_{4}$, so that $\mathrm{PO}_{4}$ is often already restored to its winter concentrations in August/September.

The DOP concentration is elevated at the time of the lowest $\mathrm{PO}_{4}$ concentration and highest primary production as is also frequently observed for the DOC concentration, but not for DON at our stations. A second period of elevated DOP concentration occurs during the decline of the bloom when POP is degraded and $\mathrm{PO}_{4}$ levels are restored. Thus, elevated DOP concentrations are indicative for the onset of periods of intensive internal cycling of $\mathrm{P}$. Phosphorus regeneration is an important process in the Southern Bight of the North Sea, which allows phytoplankton growth even at very low $\mathrm{PO}_{4}$ levels.

Acknowledgements. The authors wish to thank the captain and crew of the RV Zeeleeuw, A. Cattrijsse and F. Hernandez (VLIZ), as well as N. Roevros (ULB-LOGCE) for their logistic support. We are grateful to M. Tsagaris and C. de Marneffe (ULB-LOGCE) for their analytical work in the laboratory and to our ULB-LOGCE colleagues for their assistance at sea. R. James Evans polished our English. The comments and suggestions provided by the three anonymous reviewers and the handling editor helped to improve the clarity of this paper and are greatly appreciated. This study was supported by the Belgian Federal Science Policy Office under contract no. EV/11/20B (CANOPY). Partial funding provided by the SISCO project (contract no. EV/11/17A) is also acknowledged. This paper is dedicated to the late R. Wollast, a beloved colleague and friend, whom we miss dearly.

Edited by: A. Boetius

\section{References}

Abril, G., Nogueira, M., Etcheber, H., Cabeçadas, G., Lemaire, E., and Brogueira, M. J.: Behaviour of organic carbon in nine contrasting European estuaries, Est. Coast Shelf Sci., 54, 241-262, 2002.

Ammerman, J. W. and Azam, F.: Bacterial 5'-nucleotidase in aquatic ecosystems: A novel mechanism for phosphorus regeneration, Science, 227, 1338-1340, 1985. 
Ammerman, J. W. and Azam, F.: Bacterial 5'-nucleotidase activity in estuarine and coastal marine waters: Role in phosphorus regeneration, Limnol. Oceanogr., 36, 1437-1447, 1991.

Bishop, J. K. B., Collier, R. W., Ketten, D. R., and Edmond, J. M.: The chemistry, biology and vertical flux of particulate matter from the upper $400 \mathrm{~m}$ of the equatorial Atlantic ocean, Deep Sea Res., 24, 511-548, 1977.

Björkman, K. and Karl, D. M.: Bioavailability of inorganic and organic phosphorus compounds to natural assemblages of microorganisms in Hawaiian coastal waters, Mar. Ecol. Progr. Ser., 111, 265-273, 1994.

Borges, A. V. and Frankignoulle, M.: Distribution and air-water exchange of carbon dioxide in the Scheldt plume off the Belgian coast, Biogeochem., 59, 41-67, 2002.

Brion, N., Baeyens, W., De Galan, S., Elskens, M., and Laane, R. W. P. M.: The North Sea: source or sink for nitrogen and phosphorus to the Atlantic Ocean?, Biogeochem., 68, 277-295, 2004.

Butler, E. I., Knox, S., and Liddicoat, M. I.: The relationship between inorganic and organic nutrients in sea water, J. Mar. Biol. Ass. U.K., 59, 239-250, 1979.

Cadée, G. C. and Hegeman, J.: Phytoplankton in the Marsdiep at the end of the 20th century; 30 years of monitoring biomass, primary production and Phaeocystis blooms, J. Sea Res., 48, 97110, 2002.

Church, J. J., Ducklow, H. W., and Karl, D. M.: Multiyear increases in dissolved organic matter inventories at station ALOHA in the North Pacific Subtropical Gyre, Limnol. Oceanogr., 47, 1-10, 2002.

Clark, L. L., Ingall, E. D., and Benner, R.: Marine phosphorus is selectively remineralized, Nature, 393, 426, 1998.

Conley, D. J., Schelske, C. L., and Stoermer, E. F.: Modification of the biogeochemical cycle of silica with eutrophication, Mar. Ecol. Progr. Ser., 101, 179-192, 1993.

Dafner, E., De Galan, S., and Goeyens, L.: Microwave digestion of organic substances, a useful tool for dissolved organic nitrogen measurements, Wat. Res., 33, 548-554, 1999.

De Galan, S., Elskens, M., Goeyens, L., Pollentier, A., Brion, N., and Baeyens, W.: Spatial and temporal trends in nutrient concentrations in the Belgian continental area of the North Sea during the period 1993-2000, Est. Coast. Shelf Sci., 61, 517-528, 2004.

Duursma, E.: Dissolved organic carbon, nitrogen and phosphorus in the sea, Neth. J. Sea Res., 1, 1-148, 1961.

Eppley, R., Horrigan, S., Fuhrman, J., Brooks, E., Price, C., and Sellner, K.: Origins of dissolved organic mater in Southern California coastal waters: experiments on the role of zooplankton, Mar. Ecol. Progr. Ser., 6, 149-159, 1981.

Fisher, T. R., Harding, L. W., Stanley, D. W., and Ward, L. G.: Phytoplankton, nutrients and turbidity in the Chesapeake, Delaware and Hudson estuaries, Est. Coast. Shelf Sci., 27, 61-93, 1988.

Flynn, K. J., Opik, H., and Syrett, P. J.: Localization of the alkaline phosphatase and 5'-nucleotidase activities of the diatom Phaeodactylum tricornutum, J. Gen. Microbiol., 132, 289-298, 1986.

Furhman, J. and Shuttle, C.: Viruses in marine planktonic systems, Oceanography, 6, 51-63, 1993.

Garber, J.: Laboratory study of nitrogen and phosphorus mineralization during the decomposition of coastal plankton and seston, Est. Coast. Shelf Sci., 18, 685-702, 1984.

Grasshoff, K., Ehrhardt, M., and Kremling, K. (Eds.): Methods of Seawater Analysis, Verlag Chemie, Basel, 1983.
Gypens, N., Lancelot, C., and Borges, A. V.: Carbon dynamics and $\mathrm{CO}_{2}$ air-sea exchanges in the eutrophied coastal waters of the southern bight of the North Sea: a modeling study, Biogeosciences, 1, 147-157, 2004,

SRef-ID: 1726-4189/bg/2004-1-147.

Herbland, A., Delmas, D., Laborde, P., Sautour, B., and Artigas, F.: Phytoplankton spring bloom of the Gironde plume waters in the Bay of Biscay: early phosphorus limitation and food-web consequences, Oceanol. Acta, 21, 279-291, 1998.

Hopkinson Jr., C. S., Fry, B., and Nolin, A. L.: Stoichiometry of dissolved organic matter dynamics on the continental shelf of the northeastern U.S.A., Cont. Shelf Res., 17, 473-489, 1997.

Koroleff, F.: Direct determination of ammonia in natural waters as indophenol blue, Int. Council Expl. Sea, 9, 19-22, 1969.

Lacroix, G., Ruddick, K., Ozer, J., and Lancelot, C.: Modelling the impact of the Scheldt and Rhine/Meuse plumes on the salinity distribution in Belgian waters (southern North Sea), J. Sea Res., 52, 149-163, 2004.

Labry, C., Herbland, A., Delmas, D., Laborde, P., Lazure, P., Froidefond, J. M., Jegou, A. M., and Sautour, B.: Initiation of winter phytoplankton blooms within the Gironde plume waters in the Bay of Biscay, Mar. Ecol. Progr. Ser., 212, 117-130, 2001.

Labry, C., Herbland, A., and Delmas, D.: The role of phosphorus on planktonic production of the Gironde plume waters in the Bay of Biscay, J. Plankt. Res., 24, 97-117, 2002.

Lancelot, C.: Gross excretion rate of natural marine phytoplankton and heterotrophic uptake of excreted products in the southern North Sea, as determined by short-term kinetics, Mar. Ecol. Progr. Ser., 1, 179-186, 1979.

Lancelot, C., Billen, G., Sournia, A., Weisse, T., Colijn, F., Veldhuis, M. J. W., Davies, A., and Wassman, P.: Phaeocystis blooms and nutrient enrichment in the continental coastal zones of the North Sea, Ambio, 16, 38-46, 1987.

Lenhart, H. J., Pätsch, J., and Radach, G.: Daily nutrient loads of the European continental rivers for the years 1977-1993, Institut für Meereskunde Bibliothek, Hamburg, Germany, 1996.

Martin, J., Knauer, G., Karl, D., and Broenkow, W.: VERTEX: carbon cycling in the northeast Pacific, Deep-Sea Res., 34, 257-285, 1987.

MIDAS, Marine Information and Data Acquisition System: Flanders Marine Institute, underway data of the RV Zeeleeuw are available from http://www.vliz.be.

Mulholland, M. R., Floge, S., Carpenter, E. J., and Capone, D. G.: Phosphorus dynamics in cultures and natural populations of Trichodesmium spp., Mar. Ecol. Progr. Ser., 239, 45-55, 2002.

Nausch, M., Nausch, G., and Wasmund, N.: Phosphorus dynamics during the transition from nitrogen to phosphate limitation in the central Baltic Sea, Mar. Ecol. Progr. Ser., 266, 15-25, 2004.

North Sea Task Force: North Sea Quality Status Report (QSR), Oslo and Paris Commisions, London and International Council for the Exploration of the Sea, Copenhagen, 1993.

Orrett, K. and Karl, D. M.: Dissolved organic phosphorus production in surface waters, Limnol. Oceanogr., 32, 383-395, 1987.

OSPARCOM: Quality status report 2000, OSPAR Commission, London, available from http://www.ospar.com, 212, 2002.

Parcom: Parcom recommandation 88/2 of 17 June 1988 on the reduction in inputs of nutrients to the parties convention area, available from http://www.ospar.org, 1, 1988.

Perry, M. J.: Alkaline phosphatase activity in subtropical Central 
North Pacific waters using a sensitive fluorometric method, Mar. Biol., 15, 113-119, 1972.

Philippart, C. J. M., Cadee, G. C., van Raaphorst, W., and Riegman, R.: Long-term phytoplankton-nutrient interactions in a shallow coastal sea: Algal community structure, nutrient budgets, and denitrification potential, Limnol. Oceanogr., 45, 131-144, 2000.

Prandle, D., Hydes, D. J., Jarvis, J., and McManus, J.: The seasonal cycles of temperature, salinity, nutrients and suspended sediment in the southern North Sea in 1988 and 1989, Est. Coast. Shelf Sci., 45, 669-680, 1997.

Rousseau, V., Leynaert, A., Daoud, N., and Lancelot, C.: Diatom succession, silicification and silicic acid availability in Belgian coastal waters (southern North Sea), Mar. Ecol. Progr. Ser., 236, 61-73, 2002.

RWS, Rijkswaterstaat: Database is available from http://www. waterbase.nl.

Skogen, M. D., Søiland, H., and Svendsen, E.: Effects of changing nutrient loads to the North Sea, J. Mar. Sys., 46, 23-38, 2004.

Smith, D., Simon, M., Alldredge, A., and Azam, F.: Intense hydrolytic enzyme activity on marine aggregates and implications for rapid particle dissolution, Nature, 359, 129-142, 1992.

Smith, S. V., Swaney, D. P., Talaue-McManus, L., Bartley, J. D., Sandhei, P. T., McLaughlin, C. J., Dupara, V. C., Crossland, C. J., Buddemeier, R. W., Maxwell, B. A., and Wulff, F.: Humans, hydrology, and the distribution of inorganic nutrient loading to the ocean, BioScience, 53, 235-245, 2003.

Solorzano, L. and Sharp, J. H.: Determination of total dissolved phosphorus and particulate phosphorus in natural waters, Limnol. Oceanogr., 25, 754-758, 1980.

Sugimura, Y. and Suzuki, Y.: A high-temperature catalytic oxidation method for the determination of non-volatile dissolved organic carbon in seawater by direct injection of a liquid sample, Mar. Chem., 24, 105-131, 1988.
Suzuki, Y.: On the measurement of DOC and DON in seawater, Mar. Chem., 41, 287-288, 1993.

Tungaraza, C., Rousseau, V., Brion, N., Lancelot, C., Gichuki, J., Baeyens, W., and Goeyens, L.: Contrasting nitrogen uptake by diatom and Phaeocystis-dominated phytoplankton assemblages in the North Sea, J. Exp. Mar. Biol. Ecol., 292, 19-41, 2003.

Turk, V., Rehnstam, A., Lundberg, E., and Hagstrom, A.: Release of bacterial DNA by marine nanoflagellates, an intermediate step in phosphorus regeneration, Appl. Environ. Microbiol., 58, 37443750, 1992.

Turner, R. E., Rabalais, N. N., Justic, D., and Dortch, Q.: Future aquatic nutrient limitations, Mar. Poll. Bul., 46, 1032-1034, 2003a.

Turner, R. E., Rabalais, N. N., Justic, D., and Dortch, Q.: Global patterns of dissolved $\mathrm{N}, \mathrm{P}$ and $\mathrm{Si}$ in large rivers, Biogeochem., 64, 297-317, 2003b.

Van Bennekom, A. J. and Wetsteijn, F. J.: The winter distribution of nutrients in the southern bight of the North Sea (1961-1978) and in the estuaries of the Scheldt and the Rhine/Meuse, Neth. J. Sea Res., 25, 75-87, 1990.

Van Beusekom, J. J. E. and Brockmann, U. H.: Transformation of phosphorus in the Elbe estuary, Estuaries, 21, 518-526, 1998.

Van Boekel, W. H. M. and Veldhuis, M. J. W.: Regulation of alkaline phosphatase synthesis in Phaeocystis sp., Mar. Ecol. Prog. Ser., 61, 281-289, 1990.

Vidal, M., Duarte, C. M., and Agusti, S.: Dissolved organic nitrogen and phosphorus pools and fluxes in the central Atlantic Ocean, Limnol. Oceanogr., 44, 106-115, 1999.

Yentsch, C. S. and Menzel, D. W.: A method for the determination of phytoplankton chlorophyll and phaeophytin by fluorescence, Deep-Sea Res., 10, 221-231, 1963. 